Eur. J. Clin. Chem. Clin. Biochem.

Vol. 29, 1991, pp. 743-748

(C) 1991 Walter de Gruyter \& Co.

Berlin - New York

\title{
Diamine Oxidase Activity in Amniotic Fluid for Diagnosis of Ruptured Membranes
}

\author{
By C. M. Bank ${ }^{*}$ ), J. P. Offermans ${ }^{2}$, A. H. Gijzen ${ }^{3}$, F. Smits ${ }^{2}$, M. P. van Dieijen-Visser ${ }^{3}$ and P. J. Brombacher ${ }^{3}$ \\ ${ }^{1}$ Department of Clinical Chemistry, Stichting Streekziekenhuis Walcheren, Vlissingen, The Netherlands \\ 2 Department of Gynaecology, Academic Hospital Maastricht, Maastricht, The Netherlands \\ 2 Department of Clinical Chemistry, De Wever-Hospital, Heerlen, The Netherlands
}

(Received August 24, 1990/August 15, 1991)

Summary: Diamine oxidase in vaginal effluent is used as a parameter for ascertaining the state of fetal membranes. A new method using tritiated putrescine as a substrate is described for the determination of diamine oxidase in amniotic fluid and vaginal effluents. A number of tests are used for the diagnosis of premature rupture of fetal membranes. The described procedure for diamine oxidase activity determination can be used in general hospitals and has advantages over other parameters such as $\mathrm{pH}$, glucose or fructose concentration, and the amniotic fluid crystallization test.

\section{Introduction}

Premature rupture of fetal membranes, defined as rupture of the membranes before onset of labor, occurs in $3-14 \%$ of all births $(1-3)$. A relationship has been reported between premature rupture of fetal membranes and maternal septic morbidity and mortality (4-6). Premature rupture is also associated with increased incidence of amnionitis, fetal immaturity and fetal and infant morbidity and mortality (7-11). Management of premature rupture of fetal membranes is still controversial and diagnosis is sometimes difficult. Many procedures have been described and are still used for the diagnosis of premature rupture of fetal membranes, such as measurement of $\mathrm{pH}$, glucose and fructose in the vaginal effluent, and the amniotic fluid crystallization test (fern test) $(11-16)$. Unfortunately, none of these appears to be fully satisfactory in doubtful cases. It has been reported that amniotic fluid contains a relatively large amount of the enzyme diamine oxidase (EC 1.4.3.6), which is absent in vaginal secretions, and might be used as a marker for premature rupture of fetal membranes (3, $17-20$ ). Diamine oxidase catalyses the oxidation of

*) formerly: de Wever Hospital, Heerlen. histamine and the aliphatic diamines 1,4-diaminobutane (putrescine) and 1,5-diaminopentane (cadaverine). In human serum or plasma the diamine oxidase activity is normally low,but it is markedly increased in pregnancy (21). The diamine oxidase activity in amniotic fluid is variable, and at term the levels are lower than in maternal plasma (22).

The physiological role of the enzyme in pregnancy remains to be determined. Diamine oxidase is located in maternal decidual cells. It has been suggested that its localisation in the placenta allows the enzyme to act as a barrier to prevent the entry of histamine and polyamines into the maternal circulation (28).

The increase of diamine oxidase activity during pregnancy is thought to result from secretion or more probably from lysis of decidual cells with entry of the enzyme into the circulation (23). The increase has also been described in neoplasia, disorders of the gastrointestinal tract (24), allergic states (25) and cystic fibrosis (26).

In diagnosing early rupture of fetal membranes, it is often difficult to identify the nature of the fluid in the upper vagina. Contaminants may be blood, urine, cervical mucus, which may be secreted abundantly at 
term, fluor or semen. It has been suggested that in the absence of vaginal bleeding, diamine oxidase activity in the vaginal fluid can be used for the diagnosis of ruptured fetal membranes $(3,17-20)$. The diamine oxidase activity appears to be present in the vaginal discharge up to two hours after the appearence of amniotic fluid in the vagina (18). The overall accuracy of diamine oxidase activity determinations in vaginal fluid for diagnosing the rupture of fetal membranes, in the absence of vaginal bleeding, is reported to be $96-100 \%(17,18)$.

As vaginal fluid samples are often small in volume, a sensitive analysis is required, especially for equivocal cases of suspected fetal membrane rupture. The design of a suitable assay for diamine oxidase, which is reliable and can be used in emergency situations, has proved problematic. The spectrophotometric assay is simple to perform but requires too much sample (27). An HPLC method has been described, but is considered to be elaborate and time consuming (28).

Diamine oxidase can be elegantly measured by oxidative deamination of $\left[1-{ }^{14} \mathrm{C}\right] 1,4$-diaminobutane or $\left[1-{ }^{14} \mathrm{C}\right] 1,5$-diaminopentane. The products from these two substrates undergo non-enzymatic cyclisation to form $\left[{ }^{14} \mathrm{C}\right]$ pyrroline or $\left[{ }^{14} \mathrm{C}\right]$ piperidine, respectively, and these can be measured after extraction in the organic phase $(29-31)$.

In our study we used $\left[{ }^{3} \mathrm{H}\right] 1,4-$ diaminobutane as substrate. We investigated the relation of diamine oxidase activity in maternal serum and amniotic fluid in relation to gestational age. Sensitivity and specificity for diagnosis of the state of fetal membranes was determined from frozen vaginal fluid samples of patients and of a reference population.

\section{Patients}

Patients from the obstetric departments of the Academic Hospital Maastricht (Maastricht), De Wever-Hospital (Heerlen), and the obstetric clinic St. Elisabeth Clinic (Heerlen), were included in this study. The collection of material from patients suspected for premature rupture of fetal membranes was performed over a period of 18 months at these centres. Suspicion of premature rupture of fetal membranes was based on clinical data. The diagnosis of ruptured membranes was established if the patient had a marked continuous fluid loss and no membranes were felt at the first vaginal examination. The vaginal fluid sample from those patients was considered to be amniotic fluid. In contrast, in patients who delivered more than four weeks after the initial complaints and had an uneventful pregnancy without any vaginal fluid loss, or intact membranes were felt at the time of the delivery, the membranes were considered as intact and the vaginal fluid was considered not to be amniotic nluid.

Material was collected from 120 patients $(8.2 \%$ of the recorded number of 1469 deliveries). Sufficient information was present from 100 patients for retrospective diagnosis. These patients were included in the study, and they revealed a premature rupture of fetal membranes prevalence of $39 \%$.
For determination of diagnostic capacity and reference intervals for diamine oxidase activity, fluids of different and known origin were collected. These included amniotic fluid as well as fluids that might be found as vaginal effluent during pregnancy: urine, cervical mucus, fluor vaginalis or blood.

Amniotic fluid was collected from 145 patients with amenorrhoea of 16 to 42 weeks by amniotic puncture or by deliberately performing rupture of the fetal membranes. In cases with premature rupture of fetal membranes, midstream urine or catheter urine was obtained. Cervical mucus and fluor vaginalis were obtained only when the fetal membranes were intact. All samples were stored at $-20^{\circ} \mathrm{C}$ until examination. Gestational age was recorded.

\section{Materials and Methods}

1,4-Diaminobutane dihydrochloride (putrescine dihydrochloride, Lot No. 15F-0555) and diamine oxidase (EC 1.4.3.6, 0.06 $\mathrm{U} / \mathrm{mg}$ at $\mathrm{pH} 7.2,37^{\circ} \mathrm{C}$, D-7876, Lot No. $56 \mathrm{~F}-8130$ ) were obtained from Sigma Chemicals. [3H]1,4-diaminobutane ([2,3$\left.{ }^{3} \mathrm{H}(\mathrm{N})\right]$ putrescine dihydrochloride), $37 \mathrm{GBq} / 1$, specific activity $910 \mathrm{GBq} / \mathrm{mmol}$, was obtained from New England Nuclear (Lot No. 2299-72).

All other reagents were purchased from Merck, Darmstadt, Germany. Phosphate buffer $(0.2 \mathrm{~mol} / \mathrm{l})$ was prepared by adding a solution of $0.2 \mathrm{~mol} / 1 \mathrm{KH}_{2} \mathrm{PO}_{4}$ to a solution of $0.2 \mathrm{~mol} / \mathrm{l}$ $\mathrm{Na}_{2} \mathrm{HPO}_{4}$ until pH 7.40 was reached.

Alkaline buffer: to a saturated solution of $\mathrm{NaHCO}_{3}$ at room temperature, after filtration, $\mathrm{NaOH}(2.0 \mathrm{~mol} / \mathrm{l})$ was added until pH 12.2 was reached.

Perchloric acid solution $(1.7 \mathrm{~mol} / \mathrm{l})$ was prepared by the addition of $14.0 \mathrm{ml} 700 \mathrm{~g} / \mathrm{kg} \mathrm{HClO}$ in $\mathrm{H}_{2} \mathrm{O}$ to give a final volume of $100 \mathrm{ml}$.

Substrate solution $\left[{ }^{3} \mathrm{H}\right] 1,4$-diaminobutane/1,4-diaminobutane: $98.8 \mathrm{kBq} / \mathrm{l} / / 4.5 \mathrm{mmol} / \mathrm{l}$ was prepared in phosphate buffer.

Extraction/scintillation solution was prepared by dissolving $5.60 \mathrm{~g} \mathrm{PPO}$ in 11 toluene.

Fresh solutions were prepared every two weeks. Protein was determined by the method of Iwata et al. (32).

Radioactivity was measured with a Kontron MR 300 Liquid Scintillation Counter, with automatic background substraction of instrumental background and quench control. Counting time was 10 minutes per sample.

\section{Procedure}

All determinations were performed on coded samples in duplicate. After thawing, the samples were centrifuged for $10 \mathrm{~min}$ at $3000 \mathrm{~g}$. Determination of diamine oxidase activity, in samples other than serum or amniotic fluid, was determined after saline extraction, to avoid problems of viscosity. The samples (1 vol.) were twice mixed with isotonic saline ( 2 vol.) and centrifuged. The aqueous supernatants were mixed and used for the diamine oxidase assay. Protein was also determined in the extract. This procedure was also applied to samples from the patient group suspected of premature rupture of fetal membranes.

\section{Diamine oxidase determination}

To $500 \mu \mathrm{l}$ phosphate buffer in a disposable tube, $200 \mu$ l serum, amniotic fluid or saline extract was added and mixed. For the sample blank, $200 \mu \mathrm{l}$ perchloric acid was used. A pre-incubation was performed in closed tube for $15 \mathrm{~min}$ at $37^{\circ} \mathrm{C}$. The assay was started by the addition of $50 \mu \mathrm{li}\left[{ }^{3} \mathrm{H}\right] 1,4$-diaminobutane/1,4diaminobutane solution, the tube closed and immediately 
mixed. After exactly $60 \mathrm{~min}$ at $37^{\circ} \mathrm{C}$ the reaction was stopped by the addition of $200 \mu \mathrm{l}$ perchloric acid and immediately mixed. Serum, amniotic fluid or saline extract $(200 \mu \mathrm{l})$ was added to the sample blank.

The extraction was performed by the addition of $1 \mathrm{ml}$ alkaline buffer and $6 \mathrm{ml}$ PPO solution. After vigorously mixing for 1 minute, the tubes were centrifuged for $20 \mathrm{~min}$ at $3000 \mathrm{~g}$. The aqueous phase was separated by freezing in an ethanol-solid $\mathrm{CO}_{2}$ mixture at $-78^{\circ} \mathrm{C}$. The organic phase was decanted into counting vials, and the radioactivity was measured.

Within each run a blank, purified diamine oxidase solution $(0.5,1.0,1.5,2.0 \mathrm{U} / \mathrm{l})$ and three quality assessment samples were determined. The quality assessment samples were aliquots of amniotic fluid stored at $-20^{\circ} \mathrm{C}$.

When the coefficient of variation for duplicate determinations was greater than $10 \%$, the analysis was repeated. Enzymatic activity of the samples was calculated from interpolation of the linear calibration curve. Samples with diamine oxidase activity above $2.0 \mathrm{U} / 1$ were diluted in saline $(1: 5)$ and reanalysed.

\section{Results}

\section{Optimal assay conditions for amniotic fluid}

The $\mathrm{pH}$ optimum for diamine oxidase determination in amniotic fluid and for purified enzyme were determined. The optimal $\mathrm{pH}$ for amniotic fluid was $\mathrm{pH}$ $=7.4$. A sample size of $200 \mu \mathrm{l}$ was chosen to obtain adequate accuracy and precision.

A linear relation between incubation time and measured product was found (fig. 1) at a substrate concentration $300 \mu \mathrm{mol} / 1$. The $K_{\mathrm{m}}$, determined in a random sample of amniotic fluid, was $19 \mu \mathrm{mol} / \mathrm{l}$ (fig. 2). The chosen substrate concentration was $300 \mu \mathrm{mol} / 1$ $\left(15 \times K_{\mathrm{m}}\right)$, and at this substrate concentration no enzyme inhibition was found. Good linearity was found for diamine oxidase activity in dilutions of purified diamine oxidase in amniotic fluid.

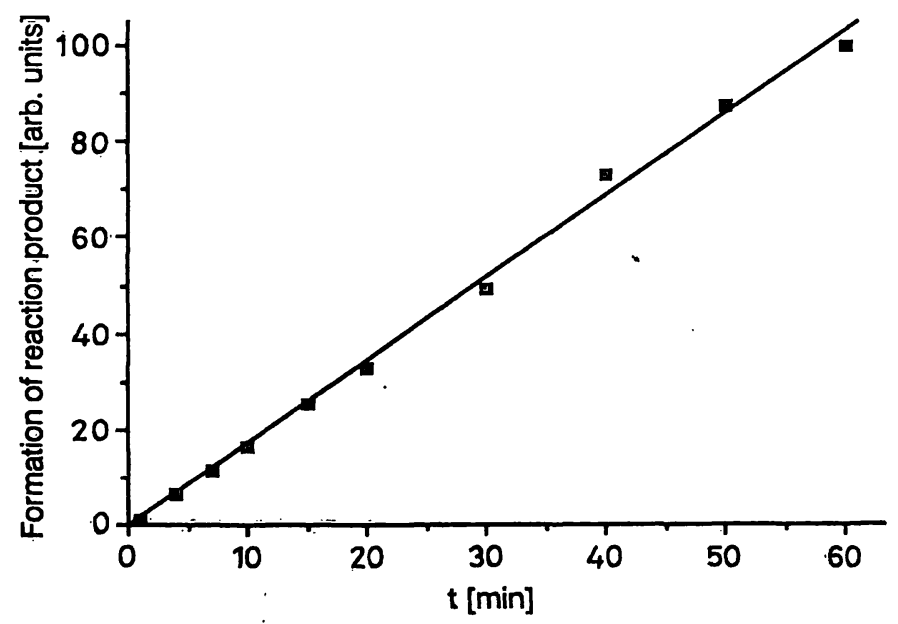

Fig. 1. Diamine oxidase activity in amniotic fluid; incubation time (minutes) versus formation of reaction product (arbitrary units). Substrate concentration $300 \mu \mathrm{mol} / \mathrm{l}$; sample volume $200 \mu \mathrm{l}$; total volume $750 \mu \mathrm{l}$.

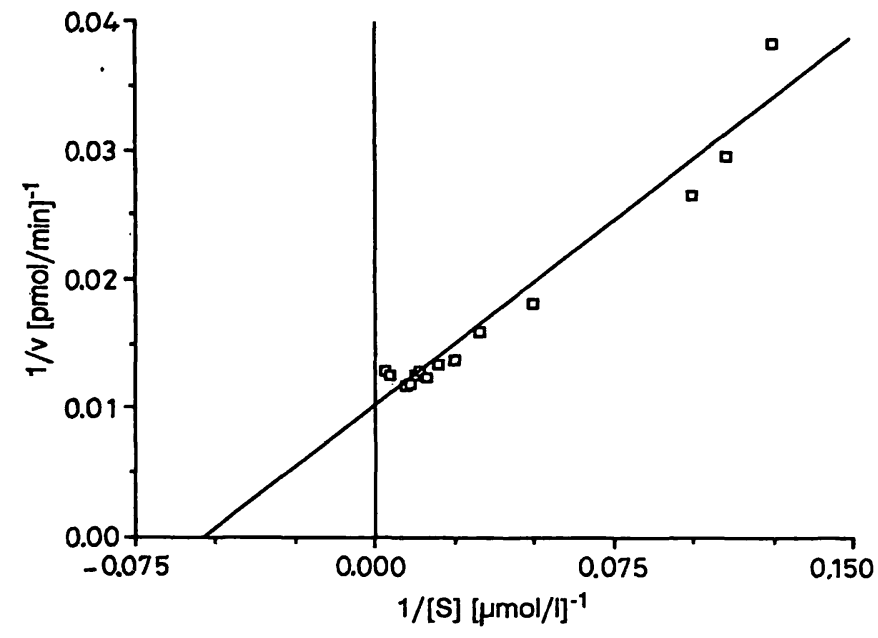

Fig. 2. Lineweaver-Burk plot for diamine oxidase in amniotic fluid. $K_{\mathrm{m}}=19 \mu \mathrm{mol} / 1$

In the tested range (up to $2 \mathrm{U} / \mathrm{l}$ ), good linearity for diamine oxidase activity was also found with dilutions of amniotic fluid and purified enzyme in saline.

\section{Blanks and controls}

Blank values were determined in each run together with controls (purified enzyme preparation). Mean count rate value for blanks was 2083 counts/min; day to day variation was $18 \%$. "Zero activity" was defined at twice the blank count rate. This was clearly different from the count rate of the lowest control $(0.27$ $\mathrm{U} / \mathrm{l})$, which had a mean value of 7516 counts/min; day to day variation was $14 \%$.

\section{Recovery and matrix effects}

Recovery of purified diamine oxidase in amniotic fluid was $98.2 \% \pm 10(n=10)$. Recovery of amnion diamine oxidase in a serum pool was $99.1 \% \pm 10$ $(\mathrm{n}=8)$.

Recovery of amnion diamine oxidase in vaginal effluent after saline extraction was $104.1 \% \pm 9.8$ $(\mathrm{n}=11)$. In urine no diamine oxidase activity was detectable. Prior to the experiment the urines were adjusted to $\mathrm{pH}$ 7.4. Recovery of diamine oxidase activity in urine after the addition of amniotic fluid was always less than $100 \%$. Figure 3 demonstrates the inhibitory effect of urine on the enzyme activity.

\section{Statistics}

The correlation coefficient of the calibration curves varied from 0.950 to 0.999 (mean $0.993, \mathrm{n}=17$ ). 


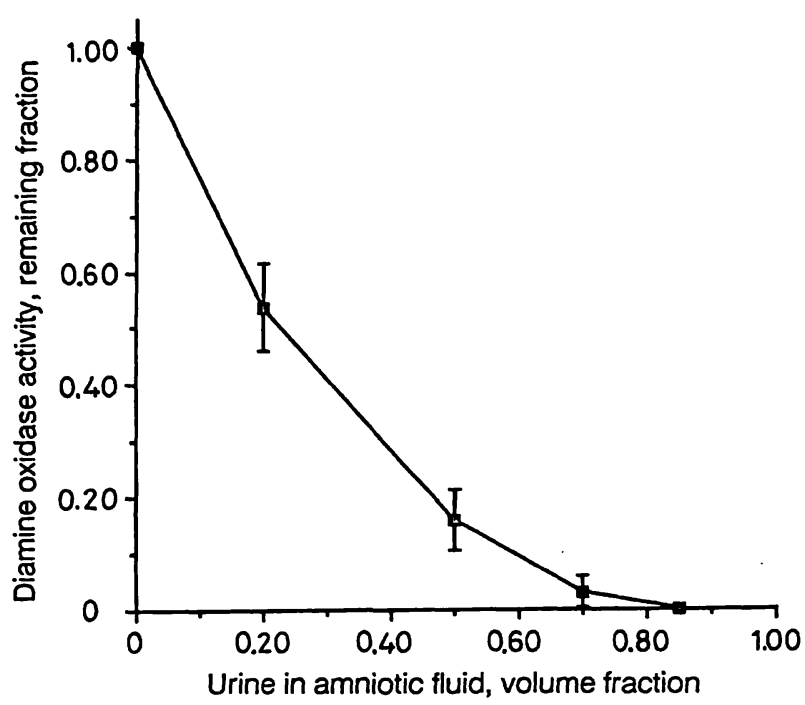

Fig. 3. Decrease of diamine oxidase activity in amniotic fluid upon increasing addition of urine.

Intra- and inter-run coefficients of variation were determined with aliquots of the three quality assessment samples (tab. 1).

\section{Reference population}

Diamine oxidase activity in amniotic fluid was measured in the reference population $(n=145)$. The results in relation to gestational age are shown in table 2. Highest values were found at $24-27$ weeks gestational age.

Diamine oxidase activity in serum was measured in an extended reference population $(n=201)$. The results in relation to gestational age are shown in table 3 .

With the exception of one fluor sample (diamine oxidase activity $1.0 \mathrm{U} / \mathrm{g}$ protein), saline extracts of fluor vaginalis $(n=58)$ and cervical mucus $(n=15)$ contained no detectable diamine oxidase activity. Protein was determined in amniotic fluid, vaginal fluid, cervical mucus and serum, in order to quantitate the effluent (tab. 4).

A number of patients' urine samples $(n=167)$ were also analysed; only 15 samples contained protein and all values were below $0.5 \mathrm{~g} / \mathrm{l}$. Moreover, a limited number $(n=15)$ of husband's semen samples were analysed, and found to contain $53.6 \pm 5.7 \mathrm{~g} / 1$ protein.

Patients suspected of premature rupture of fetal membranes

Diamine oxidase was determined in the vaginal fluid (with saline extraction) and expressed as $\mathrm{U} / \mathrm{g}$ protein.
Tab. 1. Intra- and inter-run coefficients of variation for diamine oxidase activity determination in amniotic fluid.

\begin{tabular}{lllll}
\hline Sample & \multicolumn{2}{l}{ Intra-run $(\mathrm{n}=20)$} & & \multicolumn{2}{l}{ Inter-run $(\mathrm{n}=14)$} \\
\cline { 2 - 3 } \cline { 5 - 6 } $\begin{array}{l}\text { Diamine } \\
\text { oxidase } \\
(\mathrm{U} / \mathrm{l})\end{array}$ & $\begin{array}{l}\mathrm{CV} \\
(\%)\end{array}$ & $\begin{array}{l}\text { Diamine } \\
\text { oxidase } \\
(\mathrm{U} / \mathrm{l})\end{array}$ & $\begin{array}{l}\mathrm{CV} \\
(\%)\end{array}$ \\
\hline 1 & 1.18 & 3.2 & 1.17 & 11.0 \\
2 & 1.06 & 4.3 & 1.04 & 13.2 \\
3 & 0.27 & 9.6 & 0.27 & 26.4 \\
\hline
\end{tabular}

Tab. 2. Diamine oxidase activity (mean \pm SD) in amniotic fluid in relation to gestational age (total number of patients 145).

\begin{tabular}{lll}
\hline $\begin{array}{l}\text { Amenorrhoea } \\
\text { (weeks) }\end{array}$ & $\begin{array}{l}\text { Patients } \\
\text { (n) }\end{array}$ & $\begin{array}{l}\text { Diamine oxidase } \\
\text { activity (U/1) }\end{array}$ \\
\hline $16-19$ & 12 & $0.27 \pm 0.21$ \\
$20-23$ & 8 & $1.11 \pm 1.48$ \\
$24-27$ & 14 & $1.45 \pm 1.30$ \\
$28-31$ & 12 & $0.85 \pm 0.54$ \\
$32-35$ & 25 & $0.72 \pm 0.76$ \\
$36-42$ & 74 & $0.67 \pm 0.80$ \\
\hline
\end{tabular}

Tab. 3. Diamine oxidase activity (mean \pm SD) in serum in relation to gestational age (total number of patients 201).

\begin{tabular}{|c|c|c|}
\hline $\begin{array}{l}\text { Amenorrhoea } \\
\text { (weeks) }\end{array}$ & $\begin{array}{l}\text { Patients } \\
\text { (n) }\end{array}$ & $\begin{array}{l}\text { Diamine oxidase } \\
\text { activity }(\mathrm{U} / \mathrm{l})\end{array}$ \\
\hline $\begin{array}{l}16-19 \\
20-23 \\
24-27 \\
28-31 \\
32-35 \\
36-42\end{array}$ & $\begin{array}{l}19 \\
19 \\
20 \\
26 \\
32 \\
85\end{array}$ & $\begin{array}{l}0.39 \pm 0.24 \\
0.64 \pm 0.28 \\
0.70 \pm 0.39 \\
0.76 \pm 0.40 \\
0.67 \pm 0.36 \\
0.90 \pm 1.07\end{array}$ \\
\hline
\end{tabular}

Tab. 4. Protein concentrations (mean \pm SD) in amniotic fluid, vaginal fluor, cervical mucus and serum during pregnancy.

\begin{tabular}{lllll}
\hline $\begin{array}{l}\text { Amenor- } \\
\text { rhoea } \\
\text { (weeks) }\end{array}$ & \multicolumn{4}{l}{ Protein concentration $(\mathrm{g} / \mathrm{l})$} \\
\cline { 2 - 5 } & $\begin{array}{l}\text { Amniotic } \\
\text { fluid }\end{array}$ & $\begin{array}{l}\text { Vaginal } \\
\text { fluor }\end{array}$ & $\begin{array}{l}\text { Cervical } \\
\text { mucus* }\end{array}$ & Serum \\
\hline $16-19$ & $7.3 \pm 4.9$ & $1.1 \pm 0.9$ & 0.6 & $63.7 \pm 6.7$ \\
$20-23$ & $9.1 \pm 6.8$ & $1.0 \pm 1.0$ & - & $65.5 \pm 6.6$ \\
$24-27$ & $7.2 \pm 3.7$ & $0.7 \pm 0.4$ & - & $62.1 \pm 5.2$ \\
$28-31$ & $5.3 \pm 2.3$ & $0.8 \pm 0.6$ & - & $59.8 \pm 5.7$ \\
$32-35$ & $4.0 \pm 2.1$ & $0.8 \pm 0.9$ & 0.1 & $57.6 \pm 6.2$ \\
$36-42$ & $2.8 \pm 1.2$ & $3.0 \pm 3.4$ & $5.2 \pm 2.4$ & $58.6 \pm 7.0$ \\
\hline $\begin{array}{c}\text { Number of } \\
\text { patients }\end{array}$ & 129 & 58 & 15 & 126 \\
\hline
\end{tabular}

* Cervical mucus was obtained and analysed from 15 patients in total, of whom 13 were in the last group. 
Tab. 5. Sensitivity and specificity of diamine oxidase activity in vaginal fluid for diagnosis of premature rupture of fetal membranes.

\begin{tabular}{lll}
\hline $\begin{array}{l}\text { Diamine oxidase } \\
\text { cut-off value } \\
\text { (U/g protein) }\end{array}$ & $\begin{array}{l}\text { Sensitivity } \\
(\%)\end{array}$ & $\begin{array}{l}\text { Specificity } \\
(\%)\end{array}$ \\
\hline 0 & 74.4 & 83.6 \\
0.05 & 53.8 & 90.2 \\
0.1 & 41.0 & 96.7 \\
0.2 & 23.1 & 96.7 \\
0.3 & 7.7 & 98.4 \\
0.4 & 5.1 & 98.4 \\
\hline
\end{tabular}

Values from 0 to $1.67 \mathrm{U}$ diamine oxidase per $\mathrm{g}$ protein were found. The correct diagnosis (yes/no ruptured membranes) was determined retrospectively. For diagnostic purposes Receiver Operating Characteristic (ROC) curves were determined (tab. 5, fig. 4). The optimal cut-off value appears to be at zero activity of diamine oxidase in the vaginal effluent: sensitivity $74.4 \%$, specificity $83.6 \%$. If the elevated diamine oxidase values were due to blood in the vaginal fluid, this was confirmed by elevated protein values in the effluent.

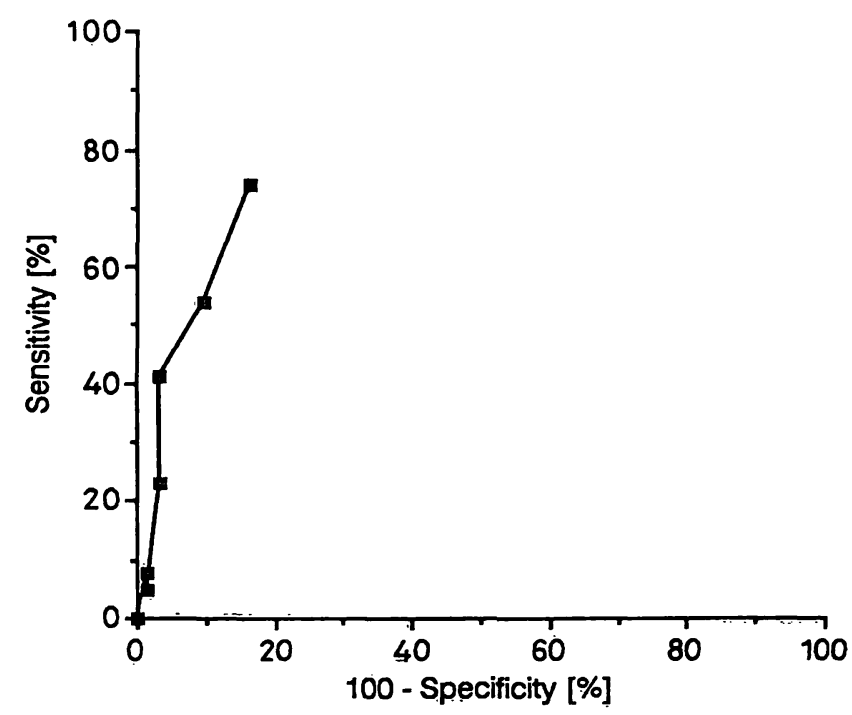

Fig. 4. Receiver Operating Characteristic (ROC) of diamine oxidase for diagnosis of premature rupture of fetal membranes (numerical data are given in table 5).

\section{References}

1. Larsen, J. W. (1979) Premature amniorrhexis. Obstet. Gynecol. Annu. 8, 203 - 221.

2. Anonymous (1979) Premature rupture of the membranes. Br: Med. J. 1, 1165-1166.

3. Gahl, W. A., Kozina, T. J., Fuhrmann, D. D. \& Vale, A. M. (1982) Diamine oxidase in the diagnosis of ruptured fetal membranes. Obstet. Gynecol. 60, 297-304.

4. Burchell, R. C. (1964) Premature spontanous rupture of the membranes. Am. J. Obstet. Gynecol. 88, 251-255.

5. Naeye,R. L. (1977) Causes of perinatal mortality in the US Collaborative Perinatal Project. J. Am. Med. Așs. 238, 228-229.

\section{Discussion}

The diagnosis premature rupture of fetal membranes is sometimes difficult to establish. This is primarily due to the lack of a measurable difference in the composition of amniotic fluid and vaginal effluent. In an attempt to overcome this problem, we determined diamine oxidase in vaginal effluent. ${ }^{14} \mathrm{C}$-labelled putrescine has been proposed as a substrate. As this label was difficult to handle in our hospital laboratory, in contrast to routine measurements using tritium, we introduced $\left[{ }^{3} \mathrm{H}\right]$ putrescine as a substrate. The intra-run reproducibility of the method was good, but the measurement technique was hampered by an inter-run coefficient of variation, at very low enzyme activity levels, of $26.4 \%$. We determined the diamine oxidase activity in the vaginal effluent of 100 patients in order to evaluate its potential as a method in the diagnosis premature rupture of fetal membranes. In all of these patients the state of the membranes was confirmed retrospectively. Prevalence of premature rupture of fetal membranes in this population was $39 \%$. The results of this study indicate that the sensitivity and specificity of the diamine oxidase activity were $74 \%$ and $84 \%$, respectively, at a cut-off value of zero diamine oxidase activity. Both the sensitivity and specificity of the diamine oxidase activity determination are higher than the sensitivity and specificity (both below $70 \%$ ) of $\mathrm{pH}$ determination and the fern test (33), which are the most common tests for detecting amniotic fluid. If diamine oxidase activity was detected,it was then necessary to determine whether this was due to amniotic fluid or blood. As the protein concentrations in blood are much higher than in amniotic fluid (upper limit below $10 \mathrm{~g} / \mathrm{l}$; tab. 4) the protein content of the effluent plays an important role in this differentiation.

On the basis of these results it is concluded that the determination of diamine oxidase activity represents a useful method for this purpose in general hospitals. However, it should be emphasized that the accuracy of $96 \%$ reported previously $(17-18)$ could not be confirmed.

6. Fayez, J. A., Hasan, A. A., Jonas, H. S. \& Miller, G. L. (1978) Management of premature rupture of the membranes. Obstet. Gynecol. 52, 17-21.

7. Webb, G. A. (1967) Maternal death associated with premature rupture of the membranes. Am. J. Obstet. Gynecol. $98,594-601$.

8. Henrion, R. (1979) Conduite à tenir devant une infection materno-fœtale. Collège national des gynécologues et obstétriciens français, 3th Journées Nationales, pp. 47-48, Paris.

9. Gunn, G. C., Mishell, D. R. Jr. \& Morton, D. G. (1970) Premature rupture of membranes: A review. Am. J. Obstet. Gynecol. 103, 469-483. 
10. Lanier, L. R. Jr., Scarbrough, R. W. Jr., Fillingim, D. W. \& Baker, R. E. Jr. (1965) Incidence of maternal and fetal complications associated with rupture of the membranes before onset of labor. Am. J. obstet. Gynecol. 93, 398404.

11. Gorodeski, I. G., Paz, M., Insler, V. \& Fishel, J. (1979) Diagnosis of rupture of the fetal membranes by glucose and fructose measurements. Obstet. Gynecol. 5, 611-616.

12. Baptesi, A. (1938) Chemical test for determination of ruptured membranes. Am. J. Gynecol. 35, 688-690.

13. Abe, T. (1940) The detection of the rupture of the fetal membranes with the nitrazine indicator. Am. J. Obstet. Gynecol. 39, 400-404.

14. Kovacs, D. (1962) Cristallization test for the diagnosis of ruptured membranes. Am. J. Obstet. Gynecol. 83, 12571260.

15. Smith, R. W. \& Callagan, C. A. (1962) Amniotic fluid cristallization test for ruptured membranes. Obstet. Gynecol. 20, 655-660.

16. Lange Friedman, M. L. \& McElin, T. W. (1969) Diagnosis of ruptured fetal membranes. Am. J. Obstet. Gynecol. 104, $544-550$

17. Elmfors, B., Tryding, N. \& Tufvesson, G. (1974) The diagnosis of ruptured membranes by measurement of diamine oxidase activity in vaginal fluid. J. Obstet. Gynaecol. Br. Commonw. 81, 361-362.

18. Wishart; 'M. M., Jenkins, D. T. \& Knott, M. L. (1979) Measurement of diamine oxidase activity in vaginal fluid. An aid to diagnosis of ruptured fetal membranes. Aust. N. Z. J. Obstet. Gynecol. 19, 23-24.

19. Schumacher, J. C., Koehl, C., Abecassis, J., Boog, G., Walch, R. \& Gander, R. (1976) Valeur de test à la diaminooxydase dans le diagnostic de rupture prématurée des membranes. Rev: Franç. Gynéc. 71, 235.

20. Vige, P., Margarie V. de, Dendrinos, S., Henrion, R., Cedard, L. \& Janssens, Y. (1984) Intérêt du test à la diamineoxydase (DAO) dans le diagnostic de la rupture spontanée des membranes ovulaires. J. Gynecol. Obstet. Biol. Reprod. Paris 13, 797-801.

21. Tryding, N. \& Willert, B. (1968) Determination of plasma diamineoxidase (histaminase) in clinical practice. Scand. J. Clin. Lab. Invest. 22, 29-32.
22. Tornqvist, A., Jonassen, F., Johnson, P. \& Fredholm, A. M. (1971) Studies on diamine oxidase activity during pregnancy. Acta Obstet. Gynec. Scand. 50, 7.9-82.

23. Baylin, S. B. \& Luk, G. D. (1981) Diamine oxidase (histaminase) activity in human disease. In: Polyamines and Biology and Medicine (Mossi, D. R. \& Marton, L. J., eds.) pp. 377-388, Marcel Dekker, ,New York.

24. Luk, G. D., Bayless, T. M., Baylin, S. B., Stevens, S. A. \& Shakir, K. M. (1978) Association of diamine oxidase and ornithine decarboxylase with maturing cells in rapidly proliferating epithelium. Biochim. Biophys. Acta 541, 415418.

25. Herman, J. J., Rosner, I. K., Davis, A. E., Zeiger, R. S., Arnaout, M. A. \& Colten, H. R. (1979) Complementdependent histaminase release from human granulocytes. J. Clin. Invest. 63, 1195-1202.

26. Baylin, S. B., Rosenstein, B. J., Marton, L. J. \& Lockwood, D. H. (1980) Age-related abnormalities of circulating polyamines and diamine activity in cystic fibrosis heterozygotes and homozygotes. Pediatr. Res. 14, 921-925.

27. Holmstedt, B., Larsson, L. \& Tham, R. (1961) Further studies of a spectrophotometric method for the determination of diamine oxidase activity. Biochim. Biophys. Acta $48,182-186$.

28. Biondi, P. A., Simonic, T., Secchi, C., Ronchi, S. \& Manzocchi, A. (1984) Sensitive assay for diamine oxidase activ= ity using high-performance liquid chromatography. J. Chromatogr. 309, $151-155$

29. Okuyama, T. \& Kobayashi, Y. (1961) Determination of diamine oxidase activity by liquid scintillation counting. Arch. Biochem. Biophys. 95, 242-250.

30. Tufvesson, G. \& Tryding, N. (1969) Determination of diamine oxidase activity in normal human blood serum. Scand. J. Clin. Lab. Invest. 24, 163-168.

31. Kusche, J. \& Lorenz, W. (1986) Diamine oxidase. In: Methods of enzymatic analysis (Bergmeyer, $\mathrm{H}$. U., ed.) vol. 3, pp. 237-250, VCH Verlagsgesellschaft $\mathrm{mbH}$, Weinheim.

32. Iwata, J. \& Nishikaze, O. (1979) New micro-turbidimetric method for determination of protein in cerebrospinal fluid and urine. Clin. Chem. 25, 1317-1319.

33. Offermans, J. P. M. (1991) De diagnostiek van de gebroken vliezen (p. 146) Thesis, University of Limburg, Maastricht (Netherlands).

Prof. Dr. P. J. Brombacher

Department of Clinical Chemistry

De Wever-Hospital

P. O. Box 4446

NL-6401 CX Heerlen 